The Astronomer Royal concluded his report as follows :

"In last year's Report, reference was made to the deterioration of the conditicns for astronomical observations at Greenwich and for the urgent need for the Observatory to be removed to a site where the conditions are favourable. At the same time the increasing magnetic disturbance at Abinger caused by the development of electric traction requires the removal of the magnetic observations to a site remote from railways, if high precision in the observations is to be attained and if the Observatory is to be secure for the future against further developments in railway electrification. A number of possible sites, both for the astronomical and for the magnetic observations, were examined during the year. The further consideration of the plans for the removal to new sites of the astronomical and magnetic observations has necessarily had to be deferred until after the conclusion of the War.

"The further improvement in accuracy of the time service provided by the Observatory has been under consideration. For purposes where high precision is needed, corrections to the time signals are published at approximately monthly intervals, after the errors of the mean clock have been satisfactorily determined from a large number of observations. The great developments in recent years in precision frequency standards and in their use have created a need, which is extending rapidly, for time signals of such precision that an interval of 24 hours can be measured to an accuracy of one thousandth of a second, without the application of corrections published after a considerable interval. This precision is not attainable with pendulum clocks, which are less accurate than the precision frequency standards themselves. The installation of a battery of quartz crystal oscillator clocks of the highest precision is required, in order that the frequency stability of modern frequency standards may be satisfactorily controlled. Conferences on this subject have been held with the Radio Section of the General Post Office and the Research Department of the British Broadcasting Corporation. The help and collaboration of these bodies and also of the National Physical Laboratory are greatly appreciated and should go far towards enabling a satisfactory scheme to be drawn up."

\title{
THE PHYLOGENY OF MAN
}

$\mathrm{P}^{\mathrm{H}}$ ROF. W. E. LE GROS CLARK, discussing recent additions to evidence bearing on the phylogeny of man (Biol. Reviews, 15, 2, 1940), begins by passing in review the fossil man-like apes, commencing with the Eocene Tarsioids and the Anthropoidea, of which the earliest representative is Parapithecus from the Oligocene of Egypt. It has now become evident that at the beginning of the Miocene the main groups of the anthropoid apes which exist to-day were already undergoing separately their evolutionary definition. It is probable that the human line of descent became first differentiated at this period and that the initial appearance of the Hominidæ is to be sought in the palæontological records of this period.

The evidence for the fossil man-like apes, the Dryopithecidæ, though widespread, consists almost entirely of teeth. Nevertheless, it points to the existence of some twenty to thirty different species, indicating that differentiation from generalized ancestors had already begun. Some of these species already show marked resemblance in dentition to man, while others approximate to the orang. In the Brahmapithecus and Ramapithecus discovered in India the resemblance to man is even more emphatically marked - so much so, indeed, that question has been raised as to the propriety of including Ramapithecus in the Simiidæ rather than the Hominidæ. A comparison with the Pleistocene apes of South Africa, of which portions of the skull are available, leaves no doubt as to their Simian status.

The evidence relating to the Miocene apes, then, suggests that they may have included among their number the direct ancestry of man. The only evidence apart from teeth, relating to the Dryopithecine groups, consists of a femur and shaft of a humerus of somewhat uncertain identification. If as is probable they are to be accepted as belonging to Dryopithecus they suggest that Dryopithecus was a 'ground-ape'; and there is every reason to believe that the human line took its origin from a form adapted to a terrestrial life.

Of the extinct man-like fossil apes of South Africa, while there can be no reasonable doubt of the human characters of the milk dentition and palate of Australopithecus, the main difficulty of interpretation lies in the attempt to assess the characters of the adult from an immature individual. Of the recently discovered Paranthropus and Plesianthropus of $\mathrm{R}$. Broom it may be accepted as an established fact that the teeth and palate in several respects are more human than those of any of the living anthropoid apes. The geological and faunal evidence alike debar them as too recent to stand in the direct line of human descent, but on the view that they derive from a dryopithecid ancestry of Miocene date, they support the conclusion that the dryopithecid stock was endowed with a potentiality of evolutionary development in the direction of the Hominidæ so far as teeth and palate are concerned.

Turning to the ape-like men, the recently discovered examples of Pithecanthropus, and especially the early infantile skull from Modjokerto, with which are here included the fossils from Choukoutien referred to the genus Sinanthropus, have served to confirm the Hominid status of the Pithecanthropus group. Despite many primitive features of the skull, brain and dentition, the limb bones are closely comparable with those of modern man. If the modern characters of the human limbs had already been acquired so early as the beginning of Pleistocene times, the point of divergence of the Hominidx from the Simiidæ must have been correspondingly more remote. 
The evolutionary origin of the Pithecanthropus group is entirely conjectural. Presumably it is derived from a dryopithecine ancestry ; but here there is a conspicuous gap in the palæontological record.

In the classical examples of Neanderthal man, the skeleton shows the development of a number of somewhat specialized characters from which it is inferred that the type could scarcely have given rise to Homo sapiens. As no transition types of later date have been found, it is legitimate to assume that Neanderthal man became extinct. It is significant that typical Neanderthal forms belong to the later phase of the period, whereas the remains belonging to the earlier part of the Mousterian epoch, such as, for example, those found at Krapina in Croatia, are less typically Neanderthaloid. This agrees with the occurrence of pre-Mousterian types (for example, Ehringsdorf, Steinheim, Swanscombe) which show a close resemblance to Homo sapiens. There can be little doubt that they were the precursors of modern man.

The Pithecanthropus group then almost certainly provided the basis for the development of later types of man. Of these, one is represented by the rather specialized Neanderthal type of later Mousterian date - an aberrant line-and a second by types of early Mousterian and pre-Mousterian date which were less distinctively Neanderthaloid and more akin in their anatomical features to Homo sapiens.

\section{DEVELOPMENTS IN ELECTRIC SURGE RECORDING}

$\mathrm{I}^{\mathrm{N}}$ 1933 a considerable amount of investigation had already taken place, chiefly outside Great Britain, with the view of determining, by means of special devices called klydonographs, the effects of lightning discharges upon overhead lines. The klydonograph is an instrument in which an electric discharge takes place on to a photographic plate or film, the resulting impression affording a record of the characteristics of the discharge. The advent of the National Grid in Great Britain stimulated interest in the subject. Whilst it was seen that the published information from various countries could be usefully applied, it was also realized that, as the results were dependent on so many variables, this needed great care, and that a similar and independent investigation could with advantage be carried out in Britain.

This was undertaken by the British Electrical and Allied Industries Research Association, with the co-operation of the Central Electricity Board and the Yorkshire Electric Power Company. The complete investigation included the use of a high-voltage cathode ray oscillograph and magnetic links in addition in continuously recording klydonographs, but only the last mentioned are to be considered here. It was agreed that these instruments could not be regarded as accurate peak surge voltmeters, but that they were capable of indicating the approximate magnitudes, polarities and times of occurrence of voltage surges.

The investigation was begun in 1933 , on an $11 \mathrm{kv}$. line owned by the Yorkshire Electric Power Co. Three klydonographs were coupled to the line by means of concentric-cylinder type capacitance 'potential-dividers'. It was soon found out that the klydonographs were not suitable for unattended use, and new ones containing many improvements were developed. Progressive elimination of defects resulted in trustworthy and satisfactory operation by May 1937, since when no noteworthy trouble has been experienced.

On April 5 J. L. Candler read a paper before the Institution of Electrical Engineers on developments in surge recording by means of the klydonograph. This paper is based on the E.R.A. report Ref. S/T 26, and is mainly concerned with the instruments and their auxiliaries. The principle of operation of the klydonograph is fairly simple. A high-voltage electrode is placed in front of and touching a photographic film. The momentary application of a high voltage across the electrode will produce a distinctive figure on the film after development. This figure is known as a photographic Lichtenburg figure or klydonogram, and from its size and type certain features of the voltage causing it can be deduced. By causing the film to slide between the electrodes at a known rate, the time of occurrence of the surge can be estimated. Generally two films and two pairs of electrodes are used. By comparing the two concurrent figures the polarity of the voltage producing them is definitely determined.

The complete instrument consists essentially of three parts: (1) a light-proof box containing the spools of unused films, the electrode system and the feed-control sprocket wheels; (2) a smaller lightproof box, containing spools on to which the used film is wound; and (3) a compartment containing two clock-work motors. Hundred foot reels of $35 \mathrm{~mm}$. film are used and the travel rate is 1 inch an hour. Thus the films last for about seven weeks, but provision is made for cutting off the used film when desired, and two interchangeable take-up boxes are provided for each instrument.

In the latest type many improvements have been introduced and little trouble is now experienced. It is essential that in making tests on klydonographs the conditions should stimulate practical conditions as nearly as possible. For this reason a test hut was erected in the field behind the laboratory building. The requisite voltage is applied by a transformer either directly or through the potential divider. Experience since 1937 indicates that mechanically the devices have attained a very high standard of perfection, and that electrically the performance cannot be improved further with this type of instrument.

No surges considered to be due to lightning were recorded on the Rayleigh-Southend line, on the lines in South Scotland or at the (G.E.B.) Creekmouth transforming station. Recording on the RotherhamDoncaster line and the Thornhill-Barugh line each yielded fifteen. Surges due to switching were numerous, but they are usually uni-directional and are approximately equally divided between the two polarities and limited to not more than twice the normal voltage. 